Folia Hort. 24/1 (2012): 41-51

DOI: $10.2478 / v 10245-012-0005-1$
Published by the Polish Society

for Horticultural Science since 1989

\title{
Tolerance to water stress in boron-deficient tea (Camellia sinensis) plants
}

\author{
Roghieh Hajiboland*, Soodabe Bastani \\ Plant Science Department \\ University of Tabriz \\ 5166614779 Tabriz, Iran
}

\begin{abstract}
The effects of boron (B) deficiency and water stress were studied in tea plants (Camellia sinensis [L.] O. Kuntze) grown in growth chambers in perlite irrigated with a nutrient solution. Dry matter production was reduced significantly by both low B supply and water stress. Shoot-root translocation of B declined in waterstressed plants. In addition, the re-translocation of B was impaired under drought, which was reflected in a significantly lower ratio of B content of young to old leaves in both B-deficient and B-sufficient plants. Leaf photochemical parameters were negatively influenced by B deficiency and water stress in the old but not in the young leaves. Although B-deficient plants were more conservative in relation to water loss following elevated stomatal limitation, their water potential was lower than in B-sufficient plants irrespective of the watering regime. Under the combined effects of $\mathrm{B}$ deficiency and water stress, the reduction in the $\mathrm{CO}_{2}$ assimilation rate was more prominent than that under a single stress factor. The reduction of the net assimilation rate $(A)$ in B-deficient plants due to water stress and in water-stressed plants due to low B supply were not accompanied by significant changes in the stomatal conductance, suggesting an involvement of non-stomatal factors. The activity of antioxidant enzymes and proline content increased under B deficiency and water stress conditions. Our results suggested that, in young leaves that have been developed under water stress, an acclimation to water stress conditions occurred that was well reflected in their more stable photochemistry, water relations and an efficient antioxidant defence system compared with the older leaves.
\end{abstract}

Key words: antioxidant defence, gas exchange, leaf photochemistry, water relations

\section{Abbreviations:}

APX - ascorbate peroxidase, B - boron, Chl - chlorophyll, $\Phi_{\mathrm{PSII}}$ - effective quantum yield of PS II, $F^{\prime} v / F^{\prime} m$ - excitation capture of open PS II, MDA - malondialdehyde, $F v / F m$ - maximum quantum yield of PS II, $A$ - net assimilation rate, $E$ - net transpiration rate, $q N$ - non-photochemical quenching, $q P$ - photochemical quenching, POD - peroxidase, ROS - reactive oxygen species, $g_{s}$ - stomatal conductance, SOD - superoxide dismutase.

\section{INTRODUCTION}

Boron (B) is an essential micronutrient required for the normal growth of higher plants. However, its function in plants has not yet been fully understood (Bolaños et al. 2004). Boron is involved in different processes such as cell enlargement and differentiation, membrane integrity and function and phenolic metabolism and sugar translocation (Marschner 1995).

\footnotetext{
*Corresponding author.

Tel.: +98 41133560 31; fax: +98 41133560 27;

e-mail: ehsan@tabrizu.ac.ir (R. Hajiboland).
} 
It has been shown that B deficiency decreases plant photosynthetic capacity (Zhao and Oosterhuis 2002). Decreased photosynthetic capacity is the result of decreased Hill reaction activity and low intercellular $\mathrm{CO}_{2}$ concentration, reduced chlorophyll (Chl) content, photosynthetic electron transport rate, photophosphorylation as well as structural damage (Plesničar et al. 1997). In turnip plants, the photosynthesis apparatus conserved its normal activities and thylakoid constituents were not damaged seriously in B-deprived leaves; however, the strongly reduced stomatal conductance accompanied by reduced leaf chlorophyll content caused a significant photo-inhibition in the leaves of B-deficient plants (Hajiboland and Farhanghi 2010).

Drought stress is a major constraint to crop production and is known to cause oxidative damage in plants as a result of the production of reactive oxygen species (ROS) (Chaves et al. 2003). Plants possess both enzymatic antioxidants such as superoxide dismutase (SOD), ascorbate peroxidase (APX) and peroxidase (POD) to overcome the toxic effect of ROS. The levels of osmoprotectants such as proline are increased in plants subjected to drought (Seki et al. 2007). The increase in free proline content and an activation of the antioxidant defence system has been reported in tea plants under drought stress (Upadhyaya et al. 2008).

The leaf water potential is the main determinant of the foliar photosynthetic rate (Reddy et al. 2004). Drought mainly limits photosynthesis through stomatal closure or metabolic impairment (Reddy et al. 2004). In addition, the inhibition of $\mathrm{CO}_{2}$ assimilation causes chloroplasts to be exposed to excessive excitation energy, increases the generation of ROS and down-regulates leaf photochemical reactions (Baker and Bowyer 1994).

Boron availability for plant roots is strongly affected by soil water (Marschner 1995). Roots absorb B mainly as non-dissociated boric acid $\left(\mathrm{H}_{3} \mathrm{BO}_{3}\right)$, which is transported to the leaves via transpiration stream. Therefore, water stress may accentuate B deficiency. However, very little information is available on this relationship and evidences on the effect of water stress on $B$ nutrition are controversial. Water stress has been shown to depress B concentration in plant parts in barley and black gram (Noppakoowong 1991) and depress B uptake and transport into young leaves, leading to increases in the external B requirement in wheat (Huang et al. 1997). In contrast, another report on wheat showed that B concentration of the flag leaf and ear was not affected by irrigation (Pant et al. 1998).

Because of the wide spectrum of B deficiency effects on plants metabolism, it is expected that B deficiency would affect the drought tolerance of plants and the extent of growth impairment by drought would be influenced greatly by B nutritional status. Boron deficiency reduces the root length of plants and causes an impaired xylem differentiation (Marschner 1995) that could strongly affect plant ability for water uptake. In turnip plants, strongly declined leaf and root B content damage to the photosynthesis apparatus, remarkable reduction of whole plant photosynthesis and disturbance in water relations are important factors contributing to the growth reduction of turnip plants under the combined effects of B deficiency and drought stress (Hajiboland and Farhanghi 2011).

Tea (Camellia sinensis [L.] O. Kuntze) is cultivated in humid and sub-humid parts of tropical, subtropical and temperate regions, usually on acidic soils. Boron deficiency is generally related to high rainfall areas and acidic soil conditions (Shorrocks 1997) common in tea plantation soils. Tea is a species susceptible to drought stress and the yield is considerably affected by water scarcity (De Costa et al. 2007). In Iran, tea is cultivated in the north of the country on acidic soils at the elevation of about $1500 \mathrm{~m}$ with an average annual rainfall of $1400 \mathrm{~mm}$. Because most of the rains fall within three months of the year, December to April, tea plantations on the hilly areas frequently encounter drought stress.

To our knowledge, there is hardly any information on the physiological responses of tea plants either to B deficiency or to water stress when combined with B starvation. The aim of this experiment was to study the effect of B nutritional status on the growth, water relations and photosynthesis of tea plants under water deficit conditions. The function of the antioxidant defence system as affected by B starvation and water limitation was also investigated in this work.

\section{MATERIAL AND METHODS}

\section{Plant culture and treatments}

A $2 \times 2$ factorial experiment including two levels of B supply and two watering regimes was conducted under controlled environmental conditions with a temperature schedule of $25 / 18^{\circ} \mathrm{C}$ day/night, $14 / 10$ h light/dark period, a relative humidity of $70 / 80 \%$ and at a photon flux density of about $400 \mu \mathrm{mol}$ $\mathrm{m}^{-2} \mathrm{~s}^{-1}$ provided by fluorescent lamps. 
Seeds of tea (Camellia sinensis [L.] O. Kuntze) plants were collected from the garden of the Tea Research Station in Fuman (Guilan Province), Iran. Hulled seeds were surface-sterilised with $1 \%$ active hypochlorite and germinated on perlite in the dark and moistened by distilled water and saturated $\mathrm{CaSO}_{4}$ every day. After the emergence of the primary leaves, seedlings were transferred to the light. Four week-old seedlings were transferred to pots filled with acid-washed $(1 \% \mathrm{HCl})$, sieved perlite (1-2 mm particles) and irrigated with water or $50 \%$ nutrient solution at $\mathrm{pH} 4.5$ (Ghanati et al. 2005) at field capacity for one week before starting treatments. Thereafter, different $\mathrm{B}$ treatments including low $(-\mathrm{B},<2.5 \mu \mathrm{M}$ as a contamination of nutrient solution) and adequate $(+\mathrm{B}, 46 \mu \mathrm{M}) \mathrm{B}$ supply and different watering regimes including $100 \%$ (control) or $50 \%$ field capacity (water stress) were applied to the pots. Pots were irrigated daily after weighing with $100 \%$ nutrient solution or water. Care was taken to avoid the accumulation of salts in the substrate by measuring EC in the perlite sampled weekly from the bottom of the pots. The volume of nutrient solution used for irrigation began with 100 $\mathrm{ml}$ per plant per week in the earlier growth phase and increased gradually and reached up to $300 \mathrm{ml}$ at the final phase of growth. Control and water-stressed plants received the same amount of nutrient solution and the respective field capacity was achieved by the different volumes of water used for irrigation.

\section{Plant harvest and analysis}

Seven weeks after starting treatments (12 weeks after sowing), the plants were harvested. After drying at $70^{\circ} \mathrm{C}$ for two days to determine dry weight (D.W.), oven-dried samples were ground using mortar and pestle and transferred to porcelain crucibles and dry-ashed with $10 \mathrm{mg} \mathrm{Ca}(\mathrm{OH})_{2}$ at $550^{\circ} \mathrm{C}$ for $5 \mathrm{~h}$, resolved in $0.5 \mathrm{M} \mathrm{HCl}$ and made up to $25 \mathrm{~mL}$ by double-distilled water. Boron content was determined following the azomethine-H method (Lohse 1982). The second youngest, fully expanded leaf, together with the third old leaf defined as young and old leaves, respectively, were used for all analyses. Fresh and dry weight and $\mathrm{B}$ content were determined in these fractions as well as in the whole plants without fractionation. Before harvest, Chl fluorescence and gas exchange parameters were determined in the attached leaves.

\section{Determination of chlorophyll fluorescence and gas exchange parameters}

Chlorophyll fluorescence parameters were recorded at harvest using a portable fluorometer (OSF1, ADC
Bioscientific Ltd., UK) for both dark adapted and light adapted leaves. An average of four records from different parts of each individual leaf was considered for each eplicate. Definitions and calculations were described elsewhere (Hajiboland and Amirazad 2010). $\mathrm{CO}_{2}$ assimilation and transpiration rates were determined in parallel with Chl fluorescence measurements in the same leaf with a calibrated portable gas exchange system (LCA-4, ADC Bioscientific Ltd., UK) between 10:00 h a.m. and 1:00 h p.m. at the leaf surface of $400 \mu \mathrm{mol} \mathrm{m}^{-2} \mathrm{~s}^{-1}$ measured by a quantum sensor attached to the leaf chamber of the gas exchange unit.

\section{Leaf osmotic potential and water potential}

Leaf osmotic potential $\left(\psi_{\pi}\right)$ and water potential $\left(\psi_{\mathrm{w}}\right)$ were determined in the second youngest leaves harvested at $1 \mathrm{~h}$ after the lights were turned on in the growth chamber. The leaves were homogenised in pre-chilled mortar and pestle and centrifuged at $4000 \mathrm{~g}$ for $20 \mathrm{~min}$ at $4^{\circ} \mathrm{C}$. The osmotic pressure of the samples was measured by an osmometer (Micro-Osmometer, Heman Roebling Messtechnik, Germany), and the miliosmol data were recalculated to Mpa. Water potential was measured using a pressure chamber (DTK-7000, Japan).

\section{Assay of antioxidant enzymes and related metabolites}

The determination of ascorbate peroxidase (APX, EC 1.11.1.11), peroxidase (POD, EC 1.11.1.7) and superoxide dismutase (SOD, EC 1.15.1.1) activity as well as the amount of malondialdehyde (MDA), $\mathrm{H}_{2} \mathrm{O}_{2}$ and proline were undertaken according to optimised protocols described elsewhere (Hajiboland and Hasani 2007). Fresh samples were ground in the presence of liquid nitrogen and measurements were undertaken using a spectrophotometer (Specord 200, Analytical Jena, Germany). Soluble proteins were determined using a commercial reagent (Sigma) and BSA (Merck) as the standard.

\section{Statistical analysis}

The experiment was undertaken in a complete randomised block design with $2 \times 2$ factors and four replications. Two-way ANOVA was performed for parameters determined in the whole plant (main effects: B supply level and watering regime) and three-way ANOVA for parameters determined in different organs (main effects: B supply level, watering regime and plant organ). Multiple comparisons of means were performed by the Tukey test $(\mathrm{p}<0.05)$ after performing two or three 
way ANOVA. The Sigma stat (3.02) package was used for statistical analysis.

\section{RESULTS}

Visual differences between B-sufficient and B-deficient plants were observed 20-25 days after starting treatments in the form of reduced shoot height. Leaf symptoms appeared only in the young leaves, and include reduced surface area, dark green colour and the rare curling of leaf lamina. The roots of B-deficient plants were poorly branched and tended to turn light purple. The shoot D.W. of plants decreased significantly under low B supply in well-watered plants, while in plants exposed to $50 \%$ field capacity it was affected only slightly by
$\mathrm{B}$ deprivation. In turn, water stress resulted in a significant reduction of shoot D.W. in B-sufficient plants, while this effect was not significant in B-deficient ones. According to the ANOVA results, there was a significant interaction between the effect of B supply level and watering regime on the dry matter production of shoots (Tab. 1). Similar with shoots, a significant reduction in root D.W. due to low B supply was only observed in well-watered plants. In addition, root D.W. was not affected significantly by water deficiency (Fig. 1).

As expected, total shoot and root B content was significantly lower in B-deficient plants compared with B-sufficient ones. Low water availability resulted in a significant reduction of shoot $B$

Table 1. The results of the ANOVA test (mean of squares) for the effect of two watering schedules: control (field capacity) and water stress (50\% field capacity) and two B supply levels: $46 \mu \mathrm{M} \mathrm{B}$ as adequate $(+\mathrm{B})$ and $<2.5 \mu \mathrm{M}$ as low B (-B), and their interactions on the physiological parameters of tea plants

\begin{tabular}{|c|c|c|c|c|c|c|c|c|c|}
\hline Parameters* & $\begin{array}{l}\text { Watering } \\
\text { schedule }\end{array}$ & Boron & Organ & $\mathrm{W} \times \mathrm{B}$ & $\mathrm{W} \times \mathrm{O}$ & $\mathrm{B} \times \mathrm{O}$ & $\mathrm{W} \times \mathrm{B} \times \mathrm{O}$ & Residual & $\mathrm{CV}$ \\
\hline Shoot D.W. & $0.285^{*}$ & $0.087^{*}$ & --- & $0.033^{*}$ & --- & --- & --- & 0.018 & 20 \\
\hline Root D.W. & $0.008^{\text {n.s. }}$ & $0.051 * * *$ & --- & $0.009^{\text {n.s. }}$ & --- & --- & --- & 0.002 & 13 \\
\hline Shoot B content & $802 *$ & $1280 * *$ & --- & $471.7^{\text {n.s. }}$ & --- & -- & --- & 159.3 & 23 \\
\hline Root B content & $24.56^{\text {n.s. }}$ & $301.8 * *$ & --- & $0.186^{\text {n.s. }}$ & --- & --- & --- & 18.49 & 16 \\
\hline Shoot B/Total B & $0.003^{*}$ & $0.000^{\text {n.s. }}$ & --- & $0.004^{\text {n.s. }}$ & --- & --- & --- & 0.002 & 6 \\
\hline Young /Old 1. B & $0.001 *$ & $0.208^{*}$ & --- & $0.038^{\text {n.s. }}$ & --- & --- & --- & 0.044 & 19 \\
\hline$F v / F m$ & $0.000^{\text {n.s. }}$ & $0.000^{\text {n.s. }}$ & $0.005^{*}$ & $0.000^{\text {n.s. }}$ & $0.000^{\text {n.s. }}$ & $0.001^{\text {n.s. }}$ & $0.000^{\text {n.s. }}$ & 0.000 & 3 \\
\hline$F^{\prime} v / F^{\prime} m$ & $0.000^{\text {n.s. }}$ & $0.001^{\text {n.s. }}$ & $0.001^{\text {n.s. }}$ & $0.000^{\text {n.s. }}$ & $0.000^{\text {n.s. }}$ & $0.001^{\text {n.s. }}$ & $0.000^{\text {n.s. }}$ & 0.000 & 3 \\
\hline$\Phi P S I I$ & $0.000^{\text {n.s. }}$ & $0.000^{\text {n.s. }}$ & $0.001^{\text {n.s. }}$ & $0.002^{\text {n.s. }}$ & $0.000^{\text {n.s. }}$ & $0.000^{\text {n.s. }}$ & $0.000^{\text {n.s. }}$ & 0.000 & 4 \\
\hline$q P$ & $0.000^{\text {n.s. }}$ & $0.000^{\text {n.s. }}$ & $0.000^{\text {n.s. }}$ & $0.005^{*}$ & $0.000^{\text {n.s. }}$ & $0.003^{\text {n.s. }}$ & $0.000^{\text {n.s. }}$ & 0.001 & 3 \\
\hline$q N$ & $0.010 * *$ & $0.006^{*}$ & $0.034 * * *$ & $0.008^{*}$ & $0.013 * *$ & $0.000^{\text {n.s. }}$ & $0.000^{\text {n.s. }}$ & 0.001 & 37 \\
\hline$A$ & $4.220 * * *$ & $1.540 * * *$ & $26.83 * * *$ & $0.149^{*}$ & $0.332 * *$ & $0.074^{\text {n.s. }}$ & $0.003^{\text {n.s. }}$ & 0.037 & 10 \\
\hline$E$ & $0.334 * *$ & $0.210 * *$ & $0.155^{*}$ & $0.054^{\text {n.s. }}$ & $0.0504^{\text {n.s. }}$ & $0.016^{\text {n.s. }}$ & $0.011^{\text {n.s. }}$ & 0.028 & 37 \\
\hline$g_{s}$ & $0.410^{* * *}$ & $0.128 * * *$ & $0.414 * * *$ & $0.056^{*}$ & $0.168^{* * *}$ & $0.036^{\text {n.s. }}$ & $0.016^{\text {n.s. }}$ & 0.009 & 48 \\
\hline$W U E$ & $7.740 * * *$ & $4.804 * *$ & $75.09 * * *$ & $19.74 * * *$ & $21.90 * * *$ & $2.451^{*}$ & $4.869 * *$ & 0.442 & 16 \\
\hline$\psi_{\pi}$ & $0.004 *$ & $0.000^{\text {n.s. }}$ & $0.000^{\text {n.s. }}$ & $0.000^{\text {n.s. }}$ & $0.000^{\text {n.s. }}$ & $0.001^{\text {n.s. }}$ & $0.000^{\text {n.s. }}$ & 0.001 & 9 \\
\hline$\psi_{\mathrm{w}}$ & $0.229^{* * *}$ & $0.217 * * *$ & $0.467 * * *$ & $0.010^{\text {n.s. }}$ & $0.0053^{\text {n.s. }}$ & $0.000^{\text {n.s. }}$ & $0.011^{\text {n.s. }}$ & 0.009 & 9 \\
\hline APX & $4256827 * * *$ & $1776185^{* * *}$ & $3195752 * * *$ & $569166^{* *}$ & $1161253 * * *$ & $1340511 * * *$ & $240936^{*}$ & 76949 & 26 \\
\hline POD & $55.32^{\text {n.s. }}$ & $4985^{* * *}$ & $13239 * * *$ & $318^{* *}$ & $137^{*}$ & $4095 * * *$ & $133^{*}$ & 41 & 33 \\
\hline SOD & $8.76^{* * *}$ & $26.49 * * *$ & $50.70 * * *$ & $5.22 * * *$ & $4.204 * * *$ & $38.96 * * *$ & $18.03 * * *$ & 0.000 & 0 \\
\hline Protein & $0.018^{\text {n.s. }}$ & $0.170^{\text {n.s. }}$ & $1.056^{* * *}$ & $0.003^{\text {n.s. }}$ & $0.085^{\text {n.s. }}$ & $0.596^{* * *}$ & $0.284^{*}$ & 0.066 & 22 \\
\hline MDA & $3466 * * *$ & $5639 * * *$ & $640 * * *$ & $194^{\text {n.s. }}$ & $379 * *$ & $1279 * * *$ & $913 * * *$ & 73.50 & 9 \\
\hline $\mathrm{H}_{2} \mathrm{O}_{2}$ & $0.790 * *$ & $0.102^{\text {n.s. }}$ & $14.06 * * *$ & $0.327^{\text {n.s. }}$ & $0.0288^{\text {n.s. }}$ & $0.155^{\text {n.s. }}$ & $0.140^{\text {n.s. }}$ & 0.116 & 26 \\
\hline Proline & $31212 * * *$ & $22016^{* * *}$ & $7099 * * *$ & $2581^{*}$ & $5513 * * *$ & $3171 * *$ & $2656^{* *}$ & 452.6 & 21 \\
\hline
\end{tabular}

*D.W. dry weight, $F_{v} / F_{m}$ (photochemical efficiency of PS II), $F_{v}^{\prime} / F_{m}^{\prime}$ (excitation capture efficiency of open PS II), $\Phi_{\text {PSII }}$ (quantum yield of PS II), $q_{P}$ (photochemical quenching) and $q_{N}$ (non-photochemical quenching), net photosynthetic rate $(A)$, transpiration rate $(E)$, stomatal conductance to water vapour $\left(g_{s}\right)$, instant water use efficiency $(W U E, A / E)$, osmotic $\left(\psi_{\pi}\right)$ and water potential $\left(\psi_{\mathrm{w}}\right)$, specific activity of ascorbate peroxidase (APX), peroxidase (POD), superoxide dismutase (SOD) and concentration of protein, malondealdehyde (MDA), hydrogen peroxide and proline

Two-way ANOVA was performed for parameters determined in whole plant and three-way ANOVA for parameters determined in different organs. n.s.: non-significant, according to Tukey test, $* * * p<0.001, * * p<0.01, * p<0.05$, CV: coefficient of variation (\%) 
content only in B-sufficient plants. Although water stress did not influence root B content, B-deficient plants had significantly lower root B content in both well-watered and water-stressed plants (Fig. 1). In order to evaluate shoot-root $B$ translocation, the ratio of shoot $\mathrm{B}$ to total $\mathrm{B}$ content of plants was calculated. This ratio was slightly or significantly decreased by both low B and water stress (Fig. 1).
In B-sufficient plants, the effect of water stress was more prominent than in B-deficient ones. The ratio of young to old leaf $\mathrm{B}$ content was presented for the purpose of finding a possible effect of the treatments on the re-translocation of B from old to young leaves. Low B supply caused a slight and significant rise in this ratio in well-watered and water-stressed plants, respectively. Low water
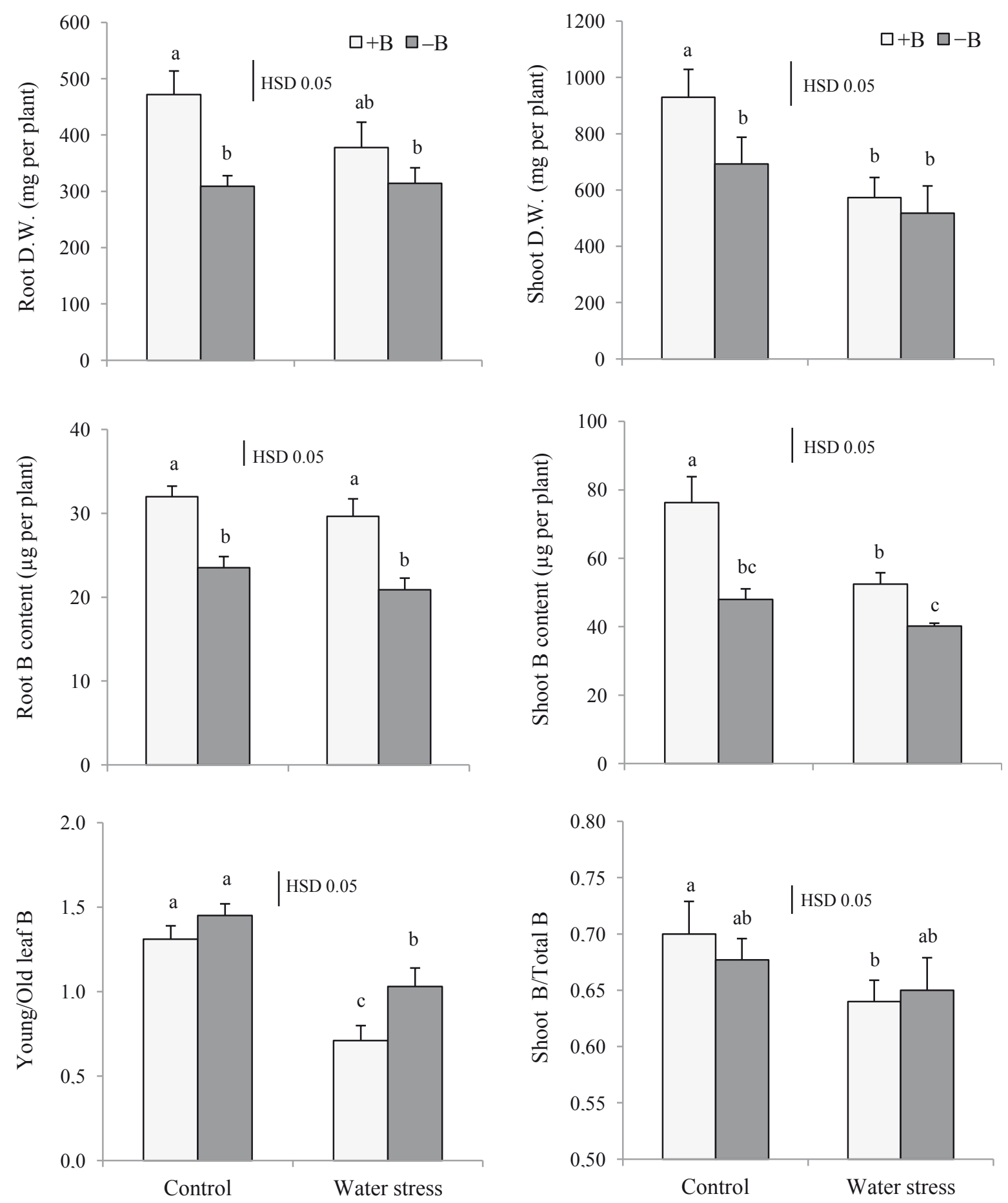

Figure 1. Effect of water stress and low B supply on dry weight and B content of various fractions of tea plants. Data are mean $\pm S D(n=4)$. Bars indicated by the same letter are not significantly different $(p<0.05)$. HSD (Honestly Significant Difference) values were designed as vertical lines. Explanations: see Table 1 
availability caused a significant reduction of this ratio in both B-sufficient and B-deficient plants (Fig. 1).

The photochemical efficiency of PS II $\left(F_{v} / F_{m}\right)$, excitation capture efficiency of open PS II $\left(F_{v}^{\prime} /\right.$ $\left.F^{\prime}{ }_{m}\right)$ and quantum yield of PS II $\left(\Phi_{\text {PSII }}\right)$ were not influenced by low B supply or water stress either in the young or in the old leaves. Photochemical $(q P)$ and non-photochemical $(q N)$ quenching were affected by treatments only in the old leaves (Tab. 2).

Thenet $\mathrm{CO}_{2}$ assimilation rate $(A)$ was significantly lower in B-deficient compared with B-sufficient plants in both well-watered and water-stressed plants. In turn, water stress caused a reduction of $A$ in both B-sufficient and B-deficient plants. Changes in $A$ were associated with changes in the stomatal conductance $\left(g_{s}\right)$. However, a significant reduction of $A$ in $\mathrm{B}$-deficient plants due to water stress and in water-stressed plants due to low B supply was not accompanied by significant changes in the $g_{s}$. ANOVA results indicated a significant interaction between the effect of B supply level and watering regime on the amounts of $A$ and $g_{s}$ (Tab. 1). The transpiration rate $(E)$ was also diminished due to $\mathrm{B}$ deficiency and water stress and consequently, the lowest amount was observed in the leaves under dual stress effects (Tab. 2).

In the young leaves, water stress caused a significant or slight increase of instant water use efficiency ( $W U E, A / E$ ), while in the old leaves of low B plants $W U E$ was lower under water deficit. Leaf osmotic potential $\left(\psi_{\pi}\right)$ was significantly diminished by water stress in both young and old leaves, but low B supply did not influence it. In contrast, the water potential $\left(\psi_{\mathrm{w}}\right)$ decreased by both applied treatments in the young and old leaves significantly or in tendency. The lowest amount of $\psi_{\mathrm{w}}$ was observed in the leaves of B deficient plants subjected to water stress (Tab. 2).

In the young leaves, APX activity significantly increased with both low B supply and water stress, while in the old leaves only water stress influenced APX activity. POD activity increased in B-deficient

Table 2. The effects of water stress and low B supply (mean $\pm \mathrm{SD} ; \mathrm{n}=4$ ) on chlorophyll fluorescence, gas exchange and water relation parameters in tea plants

\begin{tabular}{|c|c|c|c|c|c|}
\hline \multirow{2}{*}{ Parameters* } & \multirow{2}{*}{ Treatment } & \multicolumn{2}{|c|}{ Young leaf } & \multicolumn{2}{|c|}{ Old leaf } \\
\hline & & Control & Water stress & Control & Water stress \\
\hline \multirow{2}{*}{$F_{v} / F_{m}$} & $+\mathrm{B}$ & $0.78 \pm 0.02^{\mathrm{a}}$ & $0.79 \pm 0.01^{\mathrm{a}}$ & $0.76 \pm 0.01^{\mathrm{a}}$ & $0.75 \pm 0.04^{\mathrm{a}}$ \\
\hline & $-\mathrm{B}$ & $0.78 \pm 0.01^{\mathrm{a}}$ & $0.77 \pm 0.03^{\mathrm{a}}$ & $0.79 \pm 0.01^{\mathrm{a}}$ & $0.77 \pm 0.01^{\mathrm{a}}$ \\
\hline \multirow{2}{*}{$F_{v}^{\prime} / F_{m}^{\prime}$} & $+\mathrm{B}$ & $0.76 \pm 0.02^{\mathrm{a}}$ & $0.77 \pm 0.01^{\mathrm{a}}$ & $0.74 \pm 0.01^{\mathrm{a}}$ & $0.75 \pm 0.04^{\mathrm{a}}$ \\
\hline & $-\mathrm{B}$ & $0.77 \pm 0.02^{\mathrm{a}}$ & $0.77 \pm 0.01^{\mathrm{a}}$ & $0.77 \pm 0.03^{\mathrm{a}}$ & $0.77 \pm 0.01^{\mathrm{a}}$ \\
\hline \multirow{2}{*}{$\Phi_{\mathrm{PSII}}$} & $+\mathrm{B}$ & $0.71 \pm 0.01^{\mathrm{a}}$ & $0.70 \pm 0.01^{\mathrm{a}}$ & $0.70 \pm 0.01^{\mathrm{a}}$ & $0.69 \pm 0.03^{a}$ \\
\hline & $-\mathrm{B}$ & $0.71 \pm 0.01^{\mathrm{a}}$ & $0.72 \pm 0.02^{\mathrm{a}}$ & $0.69 \pm 0.06^{\mathrm{a}}$ & $0.71 \pm 0.02^{\mathrm{a}}$ \\
\hline \multirow{2}{*}{$q P$} & $+\mathrm{B}$ & $0.94 \pm 0.01^{\mathrm{a}}$ & $0.90 \pm 0.02^{\mathrm{a}}$ & $0.95 \pm 0.02^{\mathrm{a}}$ & $0.90 \pm 0.02^{b}$ \\
\hline & $-\mathrm{B}$ & $0.92 \pm 0.02^{\mathrm{a}}$ & $0.93 \pm 0.02^{\mathrm{a}}$ & $0.90 \pm 0.08^{b}$ & $0.90 \pm 0.02^{b}$ \\
\hline \multirow{2}{*}{$q N$} & $+\mathrm{B}$ & $0.16 \pm 0.04^{\mathrm{a}}$ & $0.12 \pm 0.05^{\mathrm{a}}$ & $0.14 \pm 0.05^{\mathrm{a}}$ & $0.03 \pm 0.01^{\mathrm{b}}$ \\
\hline & $-\mathrm{B}$ & $0.10 \pm 0.04^{\mathrm{a}}$ & $0.10 \pm 0.04^{\mathrm{a}}$ & $0.06 \pm 0.02^{b}$ & $0.04 \pm 0.00^{\mathrm{b}}$ \\
\hline \multirow{2}{*}{$\begin{array}{l}A \\
\mu \mathrm{mol} \mathrm{CO} \mathrm{Cm}^{-2} \mathrm{~s}^{-1}\end{array}$} & $+\mathrm{B}$ & $3.45 \pm 0.29^{\mathrm{a}}$ & $2.67 \pm 0.36^{b}$ & $1.32 \pm 0.06^{\mathrm{a}}$ & $0.92 \pm 0.03^{c}$ \\
\hline & $-\mathrm{B}$ & $2.07 \pm 0.24^{b}$ & $1.98 \pm 0.10^{\mathrm{c}}$ & $1.10 \pm 0.03^{b}$ & $0.45 \pm 0.05^{\mathrm{d}}$ \\
\hline \multirow{2}{*}{$\begin{array}{l}E \\
\mathrm{mmol} \mathrm{H}_{2} \mathrm{O} \mathrm{m}^{-2} \mathrm{~s}^{-1}\end{array}$} & $+\mathrm{B}$ & $0.98 \pm 0.20^{\mathrm{a}}$ & $0.33 \pm 0.11^{b}$ & $0.53 \pm 0.06^{\mathrm{a}}$ & $0.35 \pm 0.09 \mathrm{ab}$ \\
\hline & $-\mathrm{B}$ & $0.50 \pm 0.86^{\mathrm{b}}$ & $0.34 \pm 0.13^{b}$ & $0.36 \pm 0.11^{\mathrm{ab}}$ & $0.28 \pm 0.08^{b}$ \\
\hline \multirow{2}{*}{$\begin{array}{l}g_{s} \\
\mathrm{~mol} \mathrm{~m}^{-2} \mathrm{~s}^{-1}\end{array}$} & $+\mathrm{B}$ & $0.76 \pm 0.13^{\mathrm{a}}$ & $0.16 \pm 0.07^{b}$ & $0.18 \pm 0.01^{\mathrm{a}}$ & $0.06 \pm 0.00^{c}$ \\
\hline & $-\mathrm{B}$ & $0.27 \pm 0.03^{b}$ & $0.10 \pm 0.01^{\mathrm{b}}$ & $0.08 \pm 0.00^{\mathrm{b}}$ & $0.04 \pm 0.00^{\mathrm{d}}$ \\
\hline \multirow{2}{*}{ WUE } & $+\mathrm{B}$ & $3.52 \pm 0.92^{c}$ & $8.09 \pm 1.32^{\mathrm{a}}$ & $2.49 \pm 0.24 \mathrm{ab}$ & $2.62 \pm 0.32^{a b}$ \\
\hline & $-\mathrm{B}$ & $4.14 \pm 0.95^{b c}$ & $5.82 \pm 1.01^{\mathrm{b}}$ & $3.06 \pm 0.99^{\mathrm{a}}$ & $1.61 \pm 0.24^{b}$ \\
\hline \multirow{2}{*}{$\begin{array}{l}\psi_{\pi} \\
(\mathrm{MPa})\end{array}$} & $+\mathrm{B}$ & $-0.36 \pm 0.03^{b}$ & $-0.39 \pm 0.04^{\mathrm{a}}$ & $-0.35 \pm 0.03^{b}$ & $-0.38 \pm 0.04^{a}$ \\
\hline & $-\mathrm{B}$ & $-0.36 \pm 0.03^{\mathrm{b}}$ & $-0.37 \pm 0.04$ ab & $-0.36 \pm 0.02^{\mathrm{ab}}$ & $-0.38 \pm 0.02^{\mathrm{a}}$ \\
\hline \multirow{2}{*}{$\begin{array}{l}\psi_{\mathrm{w}} \\
(\mathrm{MPa})\end{array}$} & $+\mathrm{B}$ & $-0.68 \pm 0.05^{\mathrm{a}}$ & $-0.94 \pm 0.04^{b}$ & $-0.99 \pm 0.05^{\mathrm{a}}$ & $-1.13 \pm 0.13 \mathrm{ab}$ \\
\hline & $-\mathrm{B}$ & $-0.92 \pm 0.09^{b}$ & $-1.05 \pm 0.09^{\mathrm{b}}$ & $-1.14 \pm 0.08^{\mathrm{ab}}$ & $-1.29 \pm 0.12^{b}$ \\
\hline
\end{tabular}

Data of each parameter within each organ followed by the same letter are not significantly different $(\mathrm{p}<0.05)$

*Explanations: see Table 1 
Table 3. The effects of water stress and low B supply on the specific activity of enzymes and concentration of metabolites in tea plants. Data are mean $\pm \mathrm{SD}(\mathrm{n}=4)$

\begin{tabular}{|c|c|c|c|c|c|c|c|}
\hline \multirow{2}{*}{$\begin{array}{l}\text { Enzyme or } \\
\text { metabolite* }\end{array}$} & \multirow{2}{*}{ Treatment } & \multicolumn{2}{|c|}{ Young leaf } & \multicolumn{2}{|c|}{ Old leaf } & \multicolumn{2}{|c|}{ Root } \\
\hline & & Control & Water stress & Control & Water stress & Control & Water stress \\
\hline \multirow{2}{*}{$\begin{array}{l}\text { APX } \\
\mu \mathrm{mol} \mathrm{mg}{ }^{-1} \text { protein } \min ^{-1}\end{array}$} & $+\mathrm{B}$ & $490 \pm 24^{c}$ & $1340 \pm 215^{b}$ & $1266 \pm 246^{\mathrm{bc}}$ & $1760 \pm 144^{\mathrm{a}}$ & $362 \pm 63^{b}$ & $326 \pm 82^{b}$ \\
\hline & $-\mathrm{B}$ & $1181 \pm 135^{b}$ & $2580 \pm 596^{\mathrm{a}}$ & $1014 \pm 350^{c}$ & $1553 \pm 112^{a b}$ & $687 \pm 95^{\text {a }}$ & $743 \pm 62^{a}$ \\
\hline \multirow{2}{*}{$\begin{array}{l}\text { POD } \\
\mu \text { mol } \mathrm{mg}^{-1} \text { protein } \mathrm{min}^{-1}\end{array}$} & $+\mathrm{B}$ & $1.84 \pm 0.22^{c}$ & $1.96 \pm 0.23^{\mathrm{c}}$ & $1.32 \pm 0.33^{c}$ & $2.04 \pm 0.09^{b}$ & $34.3 \pm 6.7^{b}$ & $13.6 \pm 4.9^{\mathrm{c}}$ \\
\hline & $-\mathrm{B}$ & $3.07 \pm 0.35^{b}$ & $6.20 \pm 0.59^{\mathrm{a}}$ & $2.36 \pm 0.39^{b}$ & $4.80 \pm 0.75^{\mathrm{a}}$ & $89.3 \pm 7.5^{\mathrm{a}}$ & $82.7 \pm 6.9^{\mathrm{a}}$ \\
\hline \multirow{2}{*}{$\begin{array}{l}\mathrm{SOD} \\
\mathrm{U} \mathrm{mg^{-1 }} \text { protein }\end{array}$} & $+\mathrm{B}$ & $4.38 \pm 0.02^{\mathrm{d}}$ & $4.84 \pm 0.05^{b}$ & $4.51 \pm 0.03^{\mathrm{d}}$ & $5.88 \pm 0.05^{\mathrm{a}}$ & $5.82 \pm 0.03^{c}$ & $4.58 \pm 0.03^{\mathrm{d}}$ \\
\hline & $-\mathrm{B}$ & $4.61 \pm 0.06^{c}$ & $5.44 \pm 0.03^{\mathrm{a}}$ & $4.95 \pm 0.02^{c}$ & $5.35 \pm 0.06^{b}$ & $7.79 \pm 0.09^{b}$ & $12.77 \pm 0.06^{\mathrm{a}}$ \\
\hline \multirow{2}{*}{$\begin{array}{l}\text { Protein } \\
\mathrm{mg} \mathrm{g}^{-1} \mathrm{FW}\end{array}$} & $+\mathrm{B}$ & $1.37 \pm 0.15^{\mathrm{a}}$ & $1.24 \pm 0.23^{\mathrm{a}}$ & $1.33 \pm 0.16^{\mathrm{a}}$ & $1.02 \pm 0.10^{\mathrm{a}}$ & $1.31 \pm 0.16^{\mathrm{a}}$ & $1.03 \pm 0.17 \mathrm{ab}$ \\
\hline & $-\mathrm{B}$ & $1.35 \pm 0.15^{\mathrm{a}}$ & $1.66 \pm 0.49^{\mathrm{a}}$ & $1.21 \pm 0.52^{\mathrm{a}}$ & $1.12 \pm 0.1^{\mathrm{a}}$ & $0.77 \pm 0.14^{b}$ & $0.36 \pm 0.14^{c}$ \\
\hline \multirow{2}{*}{$\begin{array}{l}\text { MDA } \\
\text { nmol g-1 FW }\end{array}$} & $+\mathrm{B}$ & $67 \pm 15^{b}$ & $96 \pm 7^{a}$ & $72 \pm 9^{c}$ & $91 \pm 5^{b}$ & $100 \pm 8^{b}$ & $140 \pm 14^{\mathrm{a}}$ \\
\hline & $-\mathrm{B}$ & $84 \pm 13^{a b}$ & $106 \pm 8^{\mathrm{a}}$ & $108 \pm 5^{\mathrm{a}}$ & $115 \pm 5^{\mathrm{a}}$ & $82 \pm 7^{b}$ & $90 \pm 5^{b}$ \\
\hline \multirow{2}{*}{$\begin{array}{l}\mathrm{H}_{2} \mathrm{O}_{2} \\
\mu \mathrm{mol} \mathrm{g}^{-1} \mathrm{FW}\end{array}$} & $+\mathrm{B}$ & $1.80 \pm 0.32^{\mathrm{a}}$ & $1.59 \pm 0.23^{\mathrm{a}}$ & $1.73 \pm 0.21^{\mathrm{a}}$ & $2.05 \pm 0.57^{\mathrm{a}}$ & $0.13 \pm 0.03^{b}$ & $0.24 \pm 0.05^{b}$ \\
\hline & $-\mathrm{B}$ & $1.32 \pm 0.39^{\mathrm{a}}$ & $1.86 \pm 0.36^{\mathrm{a}}$ & $2.01 \pm 0.73^{\mathrm{a}}$ & $2.36 \pm 0.06^{\mathrm{a}}$ & $0.11 \pm 0.05^{b}$ & $0.49 \pm 0.16^{\mathrm{a}}$ \\
\hline \multirow{2}{*}{$\begin{array}{l}\text { Proline } \\
\text { nmol g-1 } \mathrm{FW}\end{array}$} & $+\mathrm{B}$ & $52 \pm 11^{b}$ & $78 \pm 12^{a b}$ & $91 \pm 13^{b}$ & $130 \pm 11^{\mathrm{ab}}$ & $35 \pm 4^{\mathrm{c}}$ & $80 \pm 11^{b}$ \\
\hline & $-\mathrm{B}$ & $90 \pm 19^{a}$ & $99 \pm 20^{\mathrm{a}}$ & $102 \pm 12^{b}$ & $167 \pm 41^{\mathrm{a}}$ & $64 \pm 18^{b}$ & $200 \pm 56^{\mathrm{a}}$ \\
\hline
\end{tabular}

Data of each parameter within each organ followed by the same letter are not significantly different $(\mathrm{p}<0.05)$

*Explanations: see Table 1

plants under both well-watered and water stress conditions. The constitutive activity of APX in the leaves was much greater than that in the roots, while in contrast, the constitutive POD activity in the roots was orders of magnitude higher than in the leaves. The SOD activity increased with low B supply and water stress. The ANOVA results indicated a significant interaction between the effects of $\mathrm{B}$ supply level, watering regime and age of leaves on the activity of three examined antioxidant enzymes (Tab. 1). Protein concentration was not affected by low B supply and water stress in aerial parts, while in the roots a significant or slight reduction was observed (Tab. 3).

Boron deficiency caused a significant or slight increase in the MDA content of leaves irrespective to the watering regime. On the other hand, inadequate B supply resulted in lower MDA content that was significant under water stress in roots. Combined $\mathrm{B}$ deficiency and water stress caused a significant accumulation of $\mathrm{H}_{2} \mathrm{O}_{2}$ in roots. In general, proline content increased with both low B supply and water stress conditions either significantly or slightly. The most prominent effect was observed in the roots, with up to 1.5- and 2.1-fold increase in proline content compared with their respective controls (Tab. 3).

\section{DISCUSSION}

Although shoot and root dry matter production was similarly susceptible to low B supply, water stress mainly impaired shoot DW. Consequently, the root/shoot ratio increased from 0.52 to 0.66 in B-sufficient and from 0.47 to 0.62 in B-deficient plants. Root surface area is an important criterion for plants growth under water limitation. A greater root/shoot ratio leads to a higher ability for water uptake of plants with a lower transpiration surface and could contribute in the water balance of waterstressed plants.

Shoot boron content declined dramatically not only at a low B supply but also under water deficit conditions. In plants supplied adequately by $\mathrm{B}$, proportional shoot $\mathrm{B}$ to total plant $\mathrm{B}$ was significantly lowered by water deficiency. It may imply an impairment of shoot-root translocation of $\mathrm{B}$ under water stress conditions. Roots absorb B mainly as non-dissociated boric acid $\left(\mathrm{H}_{3} \mathrm{BO}_{3}\right)$, which is transported to the leaves via the xylem that is driven by transpiration stream (Hu and Brown 1997). There has been an active debate concerning the relationship between the ion and water transport in plants. Since nutrient uptake is linked to water availability, an inhibition of stomatal conductance in draught-stressed plants could lead to reduced root-shoot B transport, which was more prominent in B-sufficient plants. In the current experiment, transpiration was strongly lowered by water stress as the result of lower stomatal conductance. $\mathrm{Hu}$ and Brown (1997) reported that transpiration is amongst the key factors that affect the uptake and 
tissue concentration of $\mathrm{B}$ and other essential mineral nutrients. Therefore, a reduction of water transport could result in nutrient deficiencies as observed for B in turnip (Hajiboland and Farhanghi 2011) and for $\mathrm{Zn}$ in red cabbage plants (Hajiboland and Amirazad 2010). Not only root-shoot transport but also re-translocation of $\mathrm{B}$ was influenced negatively by water stress conditions. Lower re-translocation of $\mathrm{B}$ under water deficit conditions was reflected in a significantly lower ratio of B content of young to old leaf. In addition, an increase in this ratio under low B supply confirmed our previous work on turnip plants (Hajiboland and Farhanghi 2010), which demonstrated higher $\mathrm{B}$ re-translocation in B-deficient plants compared to B-sufficient plants. The dramatic effect of water stress on the reduction of $\mathrm{B}$ re-translocation is likely the result of significantly lower phloem pressure flow due to water deficit that in turn lowered B re-mobilisation from old to young growing leaves. More detailed experiments are needed for study of water stress on the phloem mobility of B in plants.

Photosynthesis can be inhibited under drought even when the stomatal influence is eliminated (leaf disks without epidermis), suggesting that factors other than low $\mathrm{CO}_{2}$ availability affect photosynthesis (Tang et al. 2002). In this study, low B supply did not influence $F_{v} / F_{m}, F^{\prime}{ }_{v} / F^{\prime}{ }_{m}$ and $\Phi_{\mathrm{PSII}}$, indicating that the photosynthesis processes conserved their normal activities under B starvation and water deficiency. However, the amount of oxidised PS II reaction centres ready for reduction, i.e. photochemical quenching $(q P)$ that reflects the capacity to utilise absorbed energy through metabolism and growth, and the ability for the dissipation of excess radiation energy as heat in the light harvesting antenna of PS II, i.e. non-photochemical quenching $(q N)$, decreased significantly in the old but not in the young leaves of plants subjected either to B deficiency, low water availability or under a combination of both stresses. In this experiment, an excess of light energy likely due to either reduced photosynthetic carbon metabolism, a decrease in the $\mathrm{CO}_{2}$ available at carboxylation sites, i.e. stomatal closure, or sink limitation could be dissipated as heat through $q N$. However, old leaves under B deficiency and water stress showed a lower capacity for heat dissipation, which is likely because of the decreased xanthophyll cycle pigments, which in turn is another possible reason for the photo-inhibition reflected in lower $q P$ in the old leaves.
The different responses of young and old leaves to water stress in relation to $q P$ and $q N$ parameters could be explained with the acclimation of plants to water deficit. In leaves acclimated to water stress during their development, a higher photosynthetic rate than in non-acclimated leaves is often associated with higher electron transport rates (Flexas et al. 2009). We suggested that in the young leaves that have been developed during water stress, such acclimation could be responsible for more stable photochemistry compared with the old leaves that were emerged and developed before the imposition of water stress. It means that leaves with different growth histories may show different capacities for heat dissipation. In tea plants grown under different light intensities, photochemical events in the young leaves were more protected under excess light compared to the old leaves (Hajiboland et al. 2011), similar with the difference between light and shade leaves demonstrated for some plant species (Baker and Bowyer 1994).

Boron deficiency and low water availability lowered $g_{s}$, which was associated with the reduction of $E$ and $A$. Under B deficiency conditions, depressed $A$ as the result of elevated stomatal limitation was reported for other plant species (Han et al. 2008). Although the role of B in stomatal opening has not been investigated, because of its role in membrane integrity (Marschner 1995) and the function of $\mathrm{H}^{+}$-ATPase (Camacho-Cristóbal and GonzálezFontes 2007), B deficiency may be associated with the reduction of $\mathrm{K}^{+}$uptake into guard cells and stimulation of passive leakage of $\mathrm{K}^{+}$following the loss of membrane integrity (Hajiboland and Farhanghi 2010).

Under the combined effect of B deficiency and water stress, the $A$ reduction was more prominent than under the individual stress factors. This effect could not be attributed to the stomatal limitation but could be explained by inhibited leaf photochemistry, at least in the old leaves, as well as metabolic impairment. The activation of the carbon reduction cycle may be especially sensitive to drought (Reddy et al. 2004). The activity of Rubisco and stromal fructose-1,6-bisphosphatase decreased in B-deficient citrus leaves (Han et al. 2008). Drought mainly limits photosynthesis not only through stomatal closure but also through metabolic impairment, i.e. the reduction of Rubisco activity and ATP synthesis (Reddy et al. 2004).

Although B-deficient plants were more conservative in relation to water loss following elevated stomatal limitations, lower $\psi_{\mathrm{w}}$ in B-deficient 
plants implied that the disturbance in water economy in B-deficient plants was due to lower water uptake and not greater water loss. Water transport through the roots is very sensitive to nutrient stress (Clarkson et al. 2000). Boron deficiency likely reduces root hydraulic conductivity (Apostol and Zwiazek 2004). Boron-deficiency-induced disturbance in the formation of functional xylem vessels (Marschner $1995)$ is possibly one explanation. A decline in root hydraulic conductance may also be caused by a reduction in new root growth in B-deficient plants. According to our results, the reduction of leaf surface area under B deficiency could be also attributed to deficiency-induced disturbances in water balance as judged from lower $\psi_{\mathrm{w}}$ of B-deficient leaves observed even under well-watered conditions. It is also plausible that because of its role in $\mathrm{H}^{+}$-ATPase function, $\mathrm{B}$ deficiency causes reduction in the uptake of $\mathrm{K}^{+}$and other solutes into cells required for water uptake, cell turgidity and expansion. Lower ion accumulation is likely the cause of relatively stable amounts of $\psi_{\mathrm{s}}$ in this experiment.

The activity of both $\mathrm{H}_{2} \mathrm{O}_{2}$ metabolising enzymes, APX and POD showed a considerable increase under B deficiency and water stress conditions. Consequently, the $\mathrm{H}_{2} \mathrm{O}_{2}$ content of leaves was not changed by both applied treatments, suggesting an efficient scavenging of $\mathrm{H}_{2} \mathrm{O}_{2}$ by these enzymes. In the roots, however, a significant rise of $\mathrm{H}_{2} \mathrm{O}_{2}$ titer was detected under the combined effect of B deficiency and water stress, implying a greater production rate or lower scavenging capacity of the involved enzymes. This is likely due to the lower constitutive and stress-induced activity of APX in the roots than in the leaves. Even though the $\mathrm{H}_{2} \mathrm{O}_{2}$ content did not rise, MDA content as a product of lipid peroxidation was significantly higher under stress conditions in the old leaves. This implies the occurrence of oxidative damage, possibly following an increase in the tissue concentration of other ROS, such as superoxide radicals, which was not measured in this experiment. The increase in SOD activity was not greater than $30 \%$ in the leaves, while a 2.2 -fold increase was observed in the roots, which could likely explain the 1.2-fold lower MDA content under combined B deficiency and water stress. The greater SOD activity in the roots under the dual stresses was associated with greater proline content as well. These results are well correlated with the much lesser susceptibility of roots to both applied treatments compared with the leaves, as judged by the much more stable amounts of root dry matter production under these conditions. Molinari et al. (2007) reported a relationship between lipid peroxidation and proline accumulation in plants subjected to diverse kinds of stress. Proline acts as a free radical scavenger to protect plants from damage by oxidative stress (Wang et al. 2009) and is an important compatible osmosolute serving as a protectant for enzymes and cellular structures under drought stress (Chaves et al. 2003). Boron deficiency-induced accumulation of proline associated with the activation of antioxidant enzymes may be regarded as a strategy for tea plants to counteract the oxidative stress provoked after the subjection of deficient plants to another stress factor such as high light intensity (Hajiboland et al. 2011) and water stress in this experiment.

\section{CONCLUSIONS}

1. In spite of an increased stomatal limitation, B-deficient plants showed lower leaf water potential compared with B-sufficient ones. This implies a serious disturbance in the water economy of B-deficient plants due to lower water uptake but not greater water loss.

2. Water deficiency impaired the shoot-root translocation of B by an imposed limitation on transpiration. Moreover, the re-translocation of B from the old leaves that accumulated B in the first growth period before beginning the treatments was impaired by low water availability, likely because of lower phloem pressure flow in drought-stressed plants.

3. During the long-term water stress applied in this study, an acclimation occurred in tea plants. This acclimation was reflected in the differences between old leaves (which were emerged and developed before the imposition of water stress) and young leaves (emerged and developed during water stress) in their physiological responses to the combined effects of B deficiency and water stress. The ANOVA results confirmed the effect of leaf age on most of the examined physiological parameters as well as its significant interaction with the effect of the B supply level and watering regime.

\section{REFERENCES}

Apostol K.G., Zwiazek J.J., 2004. Boron and water uptake in jack pine (Pinus banksiana) seedlings. Environ. Exp. Bot. 51: 145-153.

BAKer N.R., Bowyer J.R., 1994. Photo-inhibition of photosynthesis. From molecular mechanisms to the field. Oxford, BIOS Scientific Publishers, UK. 
Bolanos L., Lukaszewski K., Bonilla I., Blevins D., 2004. Why boron? Plant Physiol. Biochem. 42: 907-912.

Camacho-Cristóbal J.J., González-Fontes A., 2007. Boron deficiency decreases plasmalemma $\mathrm{H}^{+}$ATPase expression and nitrate uptake, and promotes ammonium assimilation into asparagines in tobacco roots. Planta 226: 443-451.

Chaves M.M., Marco J.P., Periera S., 2003. Understanding plant responses to drought from genes to the whole plant. Funct. Plant Biol. 30: 239-64.

Clarkson D.T., Carvajal M.A., Henzler T., Waterhouse R.N., Smyth A.J., Cooke D.T., Steudle E., 2000. Root hydraulic conductance: diurnal aquaporin expression and the effects of nutrient stress. J. Exp. Bot. 51: 61-70.

De Costa W.A.J.M., Мohotti A.J., WiJeratne M.A., 2007. Ecophysiology of Tea. Braz. J. Plant Physiol. 19: 299-332.

Flexas J., Barón M., Bota J., Ducruet J-M., Gallé A., GAlmÉs J., 2009. Photosynthesis limitations during water stress acclimation and recovery in the droughtadapted Vitis hybrid Richter-110 ( $V$. berlandieri $\times V$. rupestris). J. Exp. Bot. 60: 2361-2377.

Ghanati F., Morita A., Yокота H., 2005. Effects of aluminum on the growth of tea plant and activation of antioxidant system. Plant Soil 276: 133-141.

Hajiboland R., Amirazad F., 2010. Drought tolerance in Zn-deficient red cabbage (Brassica oleracea L. var. capitata f. rubra) plants. Hort. Sci. (Prague) 37: 88-98.

Hajiboland R., Bastani S., Bahrami Rad S., 2011. Effect of light intensity on photosynthesis and antioxidant defense in boron deficient teaplants. Acta Biol. Szeged. 55: 265-272.

Hajiboland R., Farhanghi F., 2010. Remobilization of boron, photosynthesis, phenolic metabolism and antioxidant defense capacity in boron deficient turnip (Brassica rapa L.) plants. Soil Sci. Plant Nutr. 56: 427-437.

Hajiboland R., Farhanghi F., 2011. Effect of low boron supply in turnip (Brassica rapa L.) plants under drought stress. Biol. Plant. 55: 775-778.

Hajiboland R., Hasani B.D., 2007. Involvement of antioxidant defense capacity of rice and sunflower in their response to $\mathrm{Cu}$ and $\mathrm{Mn}$ toxicity under different light intensities. J. Sci. I.R. Iran 18: 103-113.

Han S., Chen L.S., Jiang H.X., Smith B.R., Yang L.T., XIE C.Y., 2008. Boron deficiency decreases growth and photosynthesis, and increases starch and hexoses in leaves of citrus seedlings. J. Plant Physiol. 165: 1331-1341.

Hu H., Brown P., 1997. Absorption of boron by plant roots. Plant Soil 93: 49-58.

Huang L., Wang K., Bell R.W., 1997. Water supply influences boron uptake by transplanted oilseed rape grown in low boron soil. In: Bell R. W., Perkasem
B. (eds). Boron in soil and plants. Kluwer Academic Publishers, Dordrecht, Netherlands:157-160.

LoHSE G., 1982. Microanalytical azomethine-H method for boron determination in plant tissues. Commun. Soil Sci. Plant Anal. 13: 127-134.

MARSCHNER H., 1995. Mineral nutrition of higher plants. $2^{\text {nd }}$ Ed., London, Academic Press, UK.

Molinari H.B.C., Marur C.J., Daros E., Campos M.K.F., Carvalho J.F.R.P., Filh J.C.B., Pereira L.F.P., Vieira L.G.E., 2007. Evaluation of the stress-inducible production of proline in transgenic sugarcane (Saccharum spp.): osmotic adjustment chlorophyll fluorescence and oxidative stress. Physiol. Plant. 130: 218-229.

Noppakoowong R., 1991. Diagnosis of boron deficiency in black gram. Ph. D dissertation, Murdoch University, Australia.

Pant J., Rerkasem B., Noppakoonwong R., 1998. Effect of water stress on the boron response of wheat genotypes under low boron field conditions. Plant Soil 202: 193-200.

Plesinčar M., Kastori R., Sakac Z., Pankovic D., Petrovic N., 1997. Boron as limiting factor in photosynthesis and growth of sunflower plants in relation to phosphate supply. Agrichimica 41: 144-154.

Reddy A.R., Chaitanya K.V., Vivekanandan M., 2004. Drought-induced responses of photosynthesis and metabolism in higher plants. J. Plant Physiol. 161: 1189-1202.

Seki M., Umezawa T., Urano K., Shinozaki K., 2007. Shinozaki Regulatory metabolic networks in drought stress responses. Curr. Opin. Plant Biol. 10: 296-302.

SHorrocks V.M., 1997. The occurrence and correction of boron deficiency. Plant Soil 193: 121-148.

Tang A.C., Kawamitsu Y., Kanechi M., Boyer J.S., 2002. Photosynthetic oxygen evolution at low water potential in leaf discs lacking an epidermis. Ann. Bot. 89: 861-870.

Upadhyaya H., Panda S.K., DutTa B.K., 2008. Variation of physiological and antioxidative responses in tea cultivars subjected to elevated water stress followed by rehydration recovery. Acta Physiol. Plant. 30: 457-468.

Wang F., Zeng B., Sun Z.X., Zhu C., 2009. Relationship between proline and $\mathrm{Hg}^{2+}$-induced oxidative stress in a tolerant rice mutant. Arch. Environ. Contam. Toxicol. 56: 723-731.

Zhao D., Oosterhuis D.M., 2002. Cotton carbon exchange, non-structural carbohydrates, and boron distribution in tissues during development of boron deficiency. Field Crop Res. 78: 75-77.

TOLERANCJA ROŚLIN HERBATY (CAMELLIA SINENSIS) Z NIEDOBOREM BORU NA STRES WODNY

Streszczenie: Badano reakcję roślin herbaty (Camellia sinensis [L.] O. Kuntze) rosnących 
w komorach wzrostowych w perlicie zasilanym roztworem nawozów na niedobór boru i stres wodny. Sucha masa roślin wytwarzana zarówno $\mathrm{w}$ warunkach niedoboru B jak i stresu wodnego była istotnie mniejsza. W warunkach stresu wodnego osłabieniu uległo przemieszczanie B z pędu do korzenia. Ponadto, w warunkach suszy zmniejszeniu uległa retranslokacja boru, co znalazło odbicie w znacznie niższym stosunku zawartości boru w liściach młodych do zawartości tego pierwiastka $\mathrm{W}$ liściach starych, zarówno $\mathrm{u}$ roślin $\mathrm{z}$ dostatecznym zaopatrzeniem $\mathrm{w}$ B jak i z niedoborem boru. Niedobór boru i stres wodny negatywnie wpłynęły na parametry fotochemiczne liści starych, ale nie młodych. Chociaż rośliny $\mathrm{z}$ niedoborem $\mathrm{B}$ były bardziej odporne na utratę wody na skutek zwiększonej oporności szparkowej, ich potencjał wodny był niższy w porównaniu do roślin $\mathrm{z}$ wystarczającym zaopatrzeniem $\mathrm{w}$ bor, niezależnie od reżimów nawadniania. W warunkach połączonego wpływu niedoboru B i stresu wodnego, zmniejszenie tempa asymilacji $\mathrm{CO}_{2}$ było większe niż w przypadku działania pojedynczego czynnika stresowego. Zmniejszeniu tempa fotosyntezy netto (A) $\mathrm{u}$ roślin $\mathrm{z}$ niedoborem boru wskutek stresu wodnego, i u roślin w warunkach suszy wskutek niskiego zaopatrzenia $\mathrm{W} B$, nie towarzyszyły istotne zmiany $\mathrm{w}$ przewodnictwie szparkowym, co sugeruje udział czynników nie związanych $\mathrm{z}$ aparatami szparkowymi. Aktywność enzymów antyoksydacyjnych oraz zawartość proliny uległy zwiększeniu w warunkach niedoboru B i stresu wodnego. Otrzymane wyniki sugerują, że młode liście, które wykształciły się w warunkach stresu wodnego, przystosowały się do warunków niedoboru wody, co znalazło odzwierciedlenie w ich bardziej stabilnych zjawiskach fotochemicznych, stosunkach wodnych i bardziej efektywnym systemem ochronnym $\mathrm{w}$ porównaniu do liści starszych.

Received November 28, 2011; accepted February 15, 2012 